Volume 10, Nomor 2, November 2018, pp 241-260 Copyright (C) 2017 Jurnal Akuntansi Maranatha, Program Studi Akuntansi, Fakultas Ekonomi,

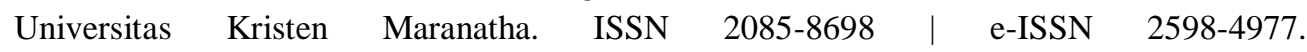
http://journal.maranatha.edu

\title{
The Effect Of Sustainability Report Disclosure and GCG Toward Firm Value Moderated By Information Asymmetry in CGPI Participants 2012-2015
}

\author{
Pera Yulianingsih \\ Memed Sueb \\ Dede Abdul Hasyir \\ Universitas Padjadjaran \\ dede.hasyir@fe.unpad.ac.id
}

\begin{abstract}
Abstrak
Tujuan penelitian ini adalah untuk mengetahui seberapa besar pengaruh pengungkapan laporan keberlanjutan dan GCG terhadap nilai perusahaan yang dimoderasi oleh asimetri informasi pada peserta CGPI 2012-2015. Metode penelitian yang digunakan dalam penelitian ini adalah deskriptif kuantitatif. Sampel adalah berbagai perusahaan yang berpartisipasi dalam CGPI Scoring. Berdasarkan hasil purposive sampling ada 8 perusahaan yang sesuai dengan kriteria selama periode observasi 2012-2015, sehingga ada 32 sampel dalam penelitian ini. Teknik analisis data yang digunakan dalam penelitian ini adalah analisis regresi linier berganda dan analisis regresi moderat. Berdasarkan uji statistik, disimpulkan bahwa pengungkapan laporan keberlanjutan berpengaruh positif signifikan terhadap nilai perusahaan, GCG tidak memiliki pengaruh signifikan terhadap nilai perusahaan, asimetri informasi memoderasi pengaruh laporan keberlanjutan terhadap nilai perusahaan, dan asimetri informasi tidak memoderasi pengaruh GCG terhadap nilai perusahaan. Kami menyarankan bahwa peneliti berikutnya untuk menggunakan proxy lain untuk mengukur GCG di samping CGPI tanpa kehilangan kelengkapannya dan dengan tambahan informasi internal dan kualitatif dan untuk memperluas ruang lingkup sampel (tidak terbatas pada peserta CGPI).
\end{abstract}

Kata kunci: Laporan Keberlanjutan, GCG, Nilai Perusahaan, dan Asimetri Informasi. 


\begin{abstract}
The purpose of this study is to find out how big the influence of sustainability report disclosure and GCG toward firm value moderated by information asymmetry in CGPI participants 2012-2015. The research method used in this study is descriptive quantitative. The samples are various firm who participate in CGPI Scoring. Based on the results of purposive sampling there are 8 firms that fit into the criteria during observation period of 2012-2015, so there are 32 samples in this research. Data analysis technique used in this research is multiple linear regression analysis and moderated regression analysis.

Based on statistical test, concluded that sustainability report disclosure has significant positive effect towards firm value, GCG has no significant effect towards firm value, information asymmetry moderated the effect of sustainability report towards firm value, and information asymmetry did not moderated the effect of GCG towards firm value. We suggest that the next researcher to use other proxy to measure GCG beside CGPI without losing it's comprehensiveness and with added internal and qualitative information and to expand the scope of the sample (not limited to CGPI participant).
\end{abstract}

Keywords: Sustainability Report, GCG, Firm Value, and Information Asymmetry.

\section{Introduction}

In the last few years, internet user especially social media in every country grew larger, information can be spread out really quickly and could have direct impact for some publicly traded companies (Kipp, 2017). Some of those information could be about firm reputation. A good reputation could increase firm value and on the other hand bad reputation can decrease firm value. In many occasion, threats to firm reputation occurs, some of it caused by negative publication about it's operational activities, especially the one that breach code of ethic.

It happened to United Airlines in April 2017 ${ }^{1}$. United Airlines' decision to forcibly eject a customer from an overbooked flight got recorded by a passenger and went viral on the internet. It

1 Shen, Lucinda. April 11, 2017. "United Airlines Stock Drops \$1.4 Billion After Passenger-Removal Controversy" http://fortune.com/2017/04/11/unitedairlines-stock-drop/

242 caused shares of United fell as much as $6.3 \%$ in pre-market trading, dropping $\$ 1.4$ billion from the now $\$ 21$ billion company by market cap. Another example from Indonesia, on April $1^{\text {st }}$, 2016, Indonesian Corruption Eradication Commission (Komisi Pemberantasan Korupsi-KPK) established CEO of PT. Agung Podomoro Land Tbk (APL) as a suspect of bribery.He alleged giving a bribe to House of Representative DKI Jakarta (DPRD DKI Jakarta). When the trading open on Monday april $4^{\text {th }}, 2016$, the APL shares took a dive as much as $10 \%^{2}$. Other cases, happened concerning environmental issue. Singapore Environmental Commissioner boycott paper-based product sales from 5 firms in Indonesia because of the way their plantation caused forest fire. Gandi, Manager Director of PT. Sinar Mas, one of the 5 firms that got banned, said that he is

\footnotetext{
${ }^{2}$ Kusuma, Dewi Rachmat (2016) "Bosnya Ditahan KPK, Saham Agung Podomoro Anjlok

10\%"https://finance.detik.com/bursa-danvalas/d-3178824/bosnya-ditahan-kpksaham-agung-podomoro-anjlok-10.
} 
worry that this step will be followed by other countries who import their paper from Indonesia. This boycott is a hard hit to the firm, furthermore Gandi said that this could be a big threat to the industry who employ 2,1 millions workers. ${ }^{3}$ Surely, if it's considered a hard hit, it will also have a big impact to profitability

From all those fact, it shows that negative publication caused investors have a negative perception thus effected firm value. Ways to resolve those are by issuing sustainability report and applying a good corporate governance practice. Djatmiko ${ }^{4}$ said, if seen in a bigger scale, lately, foreign investor who are willing to invest in Indonesia, usually look at how far the firm practice their good corporate governance. Furthermore, he said that this has been a global trend for the last two decades. Jeremy Paul Wawointana, Chief of Investment in PT Sucorinvest Asset Management ${ }^{5}$ also said that about $90 \%$ of investment portfolio placed in firms that have a GCG practice assessment.

Director of The Sustainability Accounting Standard Board, Elisse Walter (2016) said that "Investors are pushing harder and harder for this information...They are doing this through an increasing number of shareholder proposal"6. This statement also supported

${ }^{3}$ Aria, Pingit (2015) "Akibat Asap 5, Perusahaan Ini Diboikot Singapura" https://bisnis.tempo.co/read/news/2015/10/1 3/090709146/akibat-kabut-asap-5perusahaan-ini-diboikot-singapura

${ }^{4}$ Harmanto Edy Djatmiko, "GCG sebagai Pemacu Nilai Tambah" SWA, 21 Desember 2015 - 6 Januari 2016, hlm. 26.

${ }^{5}$ Vicky Rachman, "Konsisten Praktikkan GCG, Kepercayaan Investor Makin Tinggi" SWA, 20 Desember 2016 - 4 Januari 2017, hlm. 62.

${ }^{6}$ Shumsky, Tatyana (2016) "Investors Demand More Sustainability Disclosures From Companies" http://blogs.wsj.com/cfo/2016/09/26/ by a survey conducted by Ernest \& Young and Boston College in 2013 which showed almost $60 \%$ of the respondent stated that sustainability report increase firm reputation. Surely, increased firm reputation means firm value is getting higher.

Nonetheless, there are some interesting phenomena happened. PT. Garuda Indonesia who got Most Trusted Company rating (according from Corporate Governance Index Perception (CGPI) rating assessed by The Indonesian Institute for Corporate Governance (IICG) and SWA magazine) in 2010 to 2013, and then again in 2015, it's CEO become suspect of bribery in purchasing aircraft engines from Rolls Royce $\mathrm{UK}^{7}$. Meanwhile, as seen from CGPI score, this firm have been conducting GCG practice with such an outstanding score.Same corruption allegations case happened to BCA, a firm in banking industry with Most Trusted Company rating $^{8}$.

Not only real life event, but some study also showed inconsistency. Haat, et al (2008) conduct research in Malaysia concluded that GCG have no significant impact towards firm value. Nuswandari (2009) also found the same thing, she tested the effect of CGPI score towards firm value resulting in no significant influence. Then, Riandi and Siregar (2011) proved that GCG practice have no influence towards firm

investors-demand-more-sustainabilitydisclosures-from-companies/

${ }^{7}$ Afrianto, Dedy (2017) "Emirsyah Satar Jadi Tersangka, Begini Jawaban Garuda Indonesia" http://economy.okezone.com/read/2017/01/ 19/320/1595733/emirsyah-satar-jaditersangka-begini-jawaban-garuda-indonesia ${ }^{8}$ Ngazis, Amal Nur., Firdaus, Edwin (2016) "KPK Lanjutkan Usut Kasus Pajak BCA" diakses dari http://nasional.news.viva.co.id/news/read/8 57008-kpk-lanjutkan-usut-kasus-pajak-bca pada tanggal 23 Januari 2017 pukul 20.02 
value. Inconsistency also shown in research about sustainability report and firm value. Dobre, et al (2015) conducted study in Romania stated that environmental and social performance have no significant impact on financial performance which at the end firm value. Siew, et al (2013), Byus, et al (2010) and Dagiliené (2015) also have similar results.

Moreover, Nielsen Global Corporate Sustainability Report Survey $2015^{9}$ in ASEAN showed the sales of consumption product from brands that committed to sustainability only grew $4 \%$ globally since the year before. Those number considered too low to have an impact in increasing firm value. This survey also means that generally, consumers in ASEAN do not care about firm's commitment on sustainability when they choose a product. Another survey conducted by Ethical Corporation in 2015 stated that Most CFOs are not absolutely convinced of the value of firm's sustainability report.

GCG is used as controlling tool capable of prevent/reduce agency problem in a firm, seen as a positive issue by investors (Randi and Juniarti, 2013). According to agency theory, what agency problem means is occurrence of information asymmetry (Jensen and Meckling, 1976). Thus, when information asymmetry occurrence is high, management will put more effort to reduce it, for example, by issuing sustainability report and good corporate governance practice (Bahmani, 2014). By doing so, investor get the signal that firm is having a positive initiative to reduce the information asymmetry thus increasing firm value. That's why, it is concluded that information asymmetry could be moderating the relationship

${ }^{9}$ Septania, Rizky C (2015) "Sustainability, Momentum Penting Konsumen ASEAN"http://swa.co.id/swa/trends/busines s-research/sustainability-momentumpenting-konsumen-asean 244 between the influence of sustainability report disclosureand GCG towards firm value.

\section{Research Questions}

Based on introduction above, it is concluded that research question of this study are:

a. How big is the influence of sustainability report disclosure towards firm value in CGPI participant year 2012-2015.

b. How big is the influence of GCG towards firm value in CGPI participant year 2012-2015.

c. How big is the influence of sustainability report disclosure towards firm value moderated by information asymmetry in CGPI participant year 2012-2015.

d. How big is the influence of GCG towards firm value moderated by information asymmetry in CGPI participant year 2012-2015.

\section{Literature Review}

\section{Stakeholder Theory}

Freeman (1983) mentioned that the term of stakeholder is introduced by Stanford Research Institute, it means, those groups without whose support the organization would cease to exist. The point of those theory is the existence of an organization (in this case a firm) is heavily effected by the support of groups that have a relationship with it. Freeman (1983) then developed stakeholder theory and introduced these concepts in two model, business planning and policy model; and corporate social responsibility model and stakeholder management.

Meanwhile, Donaldson and Peterson (1995:73), divided stakeholder theory into three aspects:

a. The stakeholder theory is unarguably descriptive. It presents a model describing what the corporation is. It 
describes the corporation as a constellation of cooperative and competitive interests possessing intrinsic value.

b. The stakeholder theory is also instrumental. establishes a framework for examining the connections, if any, between the practice of stakeholder management and the achievement of various corporate performance goals. The principal focus of interest here has been the proposition that corporations practicing stakeholder management will, other things being equal, be relatively successful in conventional performance terms (profitability, stability, growth, etc.).

c. Its fundamental basis is normative and involves acceptance of the following ideas:

1) Stakeholders are persons or groups with legitimate interests in procedural and/or substantive aspects of corporate activity. Stakeholders are identified by their interests in the corporation, whether the corporation has any corresponding functional interest in them.

2) The interests of all stakeholders are of intrinsic value. That is, each group of stakeholders merits consideration for its own sake and not merely because of its ability to further the interests of some other group, such as the shareowners

\section{Agency Theory}

Another theory related to GCG is agency theory. Jensen and Meckling (1976) stated that agency relationship exists when one or more person (principal) hire other person (agent) to give a service and then delegate the responsibility of decision making to that agent. As an agent, manager responsible to optimize profit for principal, but on the other hand manager also have interest in maximize their own prosperity. Therefore, arise conflict of interest so there are high chance agent not always act for the best interest for principal. (Jensen and Meckling, 1976).

Eisenhardt also said the same thing, principal-agent relationship should reflect efficient organization of information and risk-bearing cost. He assumes that there is partial goal conflict among participants, efficiency as the effectiveness criterion, and information asymmetry between principal and agent.Furthermore, he added that the problem domain in agency theory is relationship in which the principal and agent have partly differing goals and risk preferences (e.g., compensation, regulation, leadership, impression management, whistle-blowing, vertical integration, transfer pricing). (Eisenhardt, 1989:58)

\section{Sustainability Report}

According to Brundtland Report published by WCED (World Commission on Environment and Development) (1987:34) sustainability should be seen as development that meets the needs of present (species) without compromising the ability of future generations to meet their own needs. Bateh, et al (2014:1) mentioned that sustainability might refer to social responsibility, ethics, or a larger piece of the strategic management rubric and has also been tied to strategic decision-making. Meanwhile American Institute of CPAs (AICPA), explain about sustainability as mention below:

"Sometimes used interchangeably with the term corporate social responsibility, the most widely accepted definition of sustainability that has emerged over time is the "triple bottom-line" consideration of

1) economic viability,

2) social responsibility, and

3)environmental responsibility.

While environmental considerations are often the focus of attention, the triplebottom-line definition of sustainability is a broad concept. In addition to preservation of the physical environment and 
stewardship of natural resources, sustainability considers the economic and social context of doing business and also encompasses the business systems, models and behaviors necessary for long-term value creation"

Therefore, the definition of sustainability report itself according to Global Reporting Initiative (GRI, 2013:13) is a report published by a company or organization about the economic, environmental and social impacts caused by its everyday activities. A sustainability report also presents the organization's values and governance model, and demonstrates the link between its strategy and its commitment to a sustainable global economy.

\section{Good Corporate Governance}

Fernando (2006:56) said that the earliest definition of corporate governance in its narrow sense is from the Economist and Nobel Laureate, Milton Friedman. According to him, "corporate governance is to conduct the business in accordance with the owner's or shareholders' desires, which generally will be to make as much money as possible, while conforming to the basic rules of the society embodied in law and local customs. While International Auditing and Assurance Standards Board(2013:216) explained that governance describes the role of person(s) or organization(s) with responsibility for overseeing the strategic direction of the entity and obligations related to the accountability of the entity.

Organization for Economic Cooperation and Development (OECD) in Agoes and Ardana (2014) try to develop some principle that can be used as guideline by government as well as business in managing the mechanism of stakeholder relationship. Those principles contain five main aspects, the rights of shareholders and on time an precise disclosure; the transparency regarding structure and firm operation; also responsibility of commissioner committee, and the boards of director to the firm, shareholders, and other party. Shortly, those principles can be concluded as: transparency, fairness, accountability, and responsibility.

\section{Information Asymmetry}

This study use information asymmetry as moderating variable. Mishkin and Eakins (2015:180) define information asymmetry as a situation that arises when one party's insufficient knowledge about the other party involved in a transaction makes it impossible to make accurate decisions when conducting the transactions. Akerlof (1970) mentioned that the existence of information asymmetry caused adverse selection problem and moral hazard. Furthermore, Mishkin and Eakins (2015:180) explained that moral hazard is a problem caused by information asymmetry when the transaction is already happened. Meanwhile, adverse selection problem is when manager and other internal party know more about the firm present condition and future projection than the investors.

\section{Firm Value}

It is difficult to define the value of a company literally, but Hticher in his book Financial Valtion: Application and Model, states that the premise of value is: "an assumption about the most likely set of transactional circumstances that may be applicable to the subject valuation." (2017: 6) Thus, when applied to the firm, firm value is an assumption about a set of transactional situations when a firm is the subject of an assessment. When investing, the goal is to buy undervalued stocks and avoid overvalued stocks (Jones, 2013: 261). Therefore, investors will see how big the cost of equity of a company. Cost of equity capital is the required rate of return of a stock. Required rate of return itself is the minimum value needed to encourage investors to buy a stock (Jones, 2013: 265).

There are several ways to calculate cost of equity capital, such as Buildup Method (BUM), Capital Asset Pricing 
Model (CAPM), Weighted Average Cost of Capital (WACC), and P / E Method (Hitchner, 2017: 153). Anyone who thinks for company appraisal can use Earning per Share (EPS), but Jones (2013: 266) argues that compared to EPS, Dividend Discount Model is more feasible. Furthermore, Jones explained, EPS is the concept of accounting, while dividends are cash payments. Investors can not issue EPS, but they can spend the dividends received. Shareholders may plan to sell their shares in the future, resulting in cash flow from the sale price. If investors think about the cash flow flow from ordinary shares as a combination of dividends and future prices in which stocks can be sold, this is equivalent to evaluating the flow of all dividends to be received. Therefore, we can concentrate on the expected future dividend of the company and the required rate of return accordingly. (Jones, 2013: 266).

\section{Prior Research and Hypotheses}

The publication of sustainability report and the implementation of good corporate governance is one form of corporate communication from the management to the stakeholders. With the expectation, the disclosure of corporate initiatives in suistainable operations and applying good corporate governance can increase investor and community confidence in general, thereby increasing the company's operational output (corporate performance) and ultimately enhancing the company's value. With the company's initiative to publish sustainability report and implement the good corporate governance is an effort to legitimize their business. With the hope of getting legitimacy from the society (society), of course the company can have a good reputation that can ultimately increase the value of the company.

Studies show that the disclosure of sustainability reports has a role in the creation of corporate value. Bachoo et al (2013: 83) in Australia, SemeNova, et al (2014: 287) in Sweden and Fatchan and
Trisnawati (2016: 32) in Indonesia. According to him, companies with high levels of disclosure sustainability report on environmental and social aspects, tend to have high corporate value as well. Randi \& Juniarti (2013: 308) explains how agency theory resolves or reduces the conflict of interest between interested parties in adverse business activities. In order to avoid conflict, the basic principles of good corporate governance are required. Corporate governance, which is a concept based on agency theory, is expected to serve as a tool to give investors confidence that they will get the same information and complete with that of management. Putra and Simanungkalit (2014: 100) mention that good corporate governance is a bridge for both stakeholders in a company, principal and agent. According to the results of their research, the implementation of good corporate governance indirectly affects the increase in corporate value. Researchers from Germany and the Netherlands, Claessens and Yurtoglu (2012: 13) also mentioned that the quality of a good corporate governance framework affects company value.

However, it turns out there are some previous studies that mention that GCG does not affect the value of the company. Haat, et al (2008) conducted a study in Malaysia that concluded that GCG had no significant and negative correlation to firm value measured using Tobin's Q. GCG in the study was measured by assessing the independence of the board of commissioners, cross-directorship of the board, and managerial ownership.

In addition, a study conducted by Nuswandari (2009) that examined the effect of CGPI on Tobin's Q value on firms listed on the BEI found that CGPI variables did not statistically affect. Then, the same is also found by Riandi and Siregar (2011) Gherghina (2015).

Proponents of stakeholder theory argue that earnings maximizing behavior may be able to adapt to the social 
framework in which well-functioning institutions establish the right fiscal rules and incentives for optimal individual and social reconciliation. However, not surviving in an economic environment filled with conflict of interest, agency costs and information asymmetry on weak institutions can not perform their duties (Becchetti and Ciciretti, 2008: 3).

From the above statement, it can be concluded that information asymmetry becomes one of the factors that can strengthen or weaken the relationship between sustainability report disclosure and GCG to company value. This is supported by Diebecker and Sommer (2016: 515) examining the relationship between corporate sustainability performance and information asymmetry on the European Stock Exchange. They found that corporate sustainability performance is more useful in reducing information asymmetry in countries where corporate sustainability performance activities serve as a substitute for institutional forms of stakeholder participation. However, corporate sustainability performance information, especially disclosure, also has a complementary or complementary effect.

This is reinforced by MartinezFerrero, et al (2016: 229) which suggests that voluntary disclosure such as CSR can suppress information asymmetry which can then increase capital market confidence and ultimately increase company value. From various research above can be concluded that influence pengunkapan sustainability report to company value can be moderated by information asymmetry. It is also supported by Chen and Liu (2013), who conducted research on the influence of corporate governance practices affecting firm value under conditions of information asymmetry. Chen and Liu (2013: 289) found that the impact of GCG had a significant effect on firm value, with increasingly reduced / reduced information asymmetry.
Bachoo, et al (2013) uses the size or size of the company in its research as a control variable. They then revealed that size was included in the study because large firms tend to have low cost of equity capital, possibly due to lower risk (Bachoo, et al, 2013: 75). So in this study used the size or size of the company as a control variable in viewing the effect of disclosure sustainability report on the value of the company. As mentioned by Zhu (2014) above, better corporate governance practices can be linked to firm value and profitability. Furthermore, in his research Zhu (2014) includes profitability as a control variable, because profitability is considered to increase also the value of the company. Therefore, in this study also use profitability as a control variable. In addition to profitability, Zhu (2014) also uses leverage as a control variable. Then Zhu (2014: 400) explains, empirical evidence shows that firms with high leverage are subject to heavy debt obligations and have a high default risk. Surely it will affect the value of the company. Therefore, in this study also use leverage as a control variable.

Based on explanation above, therefore the hypothesis for this study are: H1: The disclosure of sustainability report significantly influences the value of the company in CGPI participants in 20122015.

$\mathrm{H} 2$ : GCG significantly influences the value of the company in CGPI participating companies in 2012-2015.

H3: Disclosure of sustainability report significantly influences firm value by moderated by information asymmetry at CGPI participant companies in 2012-2015.

H4: GCG affects significantly against firm value by moderated by information asymmetry at CGPI participants in 20122015. 


\section{Research Methods}

This study uses descriptive analysis and associative with quantitative approach. Researcher gather historical data and observe certain aspect that relevant with the research question. Those data were processed and analyze until information regarding the research question can be concluded.

\section{Operational Variables}

Table 1 shows what are the object of this study, definition, and also measurement.

\section{Table 1}

Operational Variables

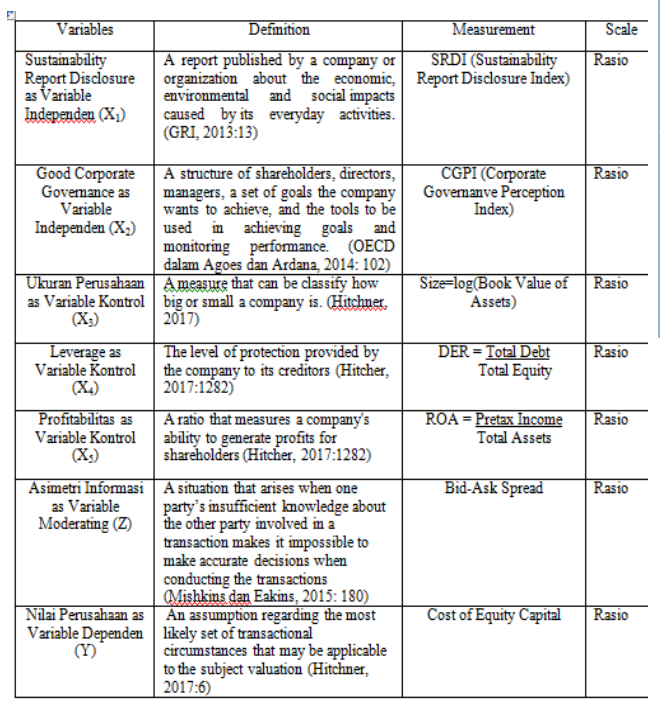

\section{Population and Samples}

Every firm that have been a participant in CGPI scoring starting from 2012 to 2015 are chosen to be population in this study. There are 11 company during 4 observation years, thus makes 44 in total. We used purposive sampling technique to choose sample with criteria below:

1. The company have to be listed in Indonesia Stock Exchange for 4 years during 2012 to 2015 .
2. The company have to issue sustainability report for 4 years during 2012 to 2015.

3. The company paid dividend to its shareholders.

After screening above, the company chosen to be sample are:

Table 2

List of Sample

\begin{tabular}{|c|c|}
\hline No. & Nama Perusahaan \\
\hline 1 & PT. Aneka Tambang (Persero) Tbk \\
\hline 2 & PT. Bank Mandiri (Persero) Tbk \\
\hline 3 & $\begin{array}{l}\text { PT. Bank Negara Indonesia } \\
\text { (Persero) Tbk }\end{array}$ \\
\hline 4 & $\begin{array}{l}\text { PT. Bank } \\
\text { (Persero) Tbk }\end{array}$ \\
\hline 5 & $\begin{array}{l}\text { PT. Bank Tabungan Negara } \\
\text { (Persero) Tbk }\end{array}$ \\
\hline 6 & PT. Bukit Asam (Persero) Tbk \\
\hline 7 & PT. Jasa Marga (Persero) Tbk \\
\hline 8 & PT. Timah (Persero) Tbk \\
\hline
\end{tabular}

As seen above, there are 8 companies

during 4 observation years, therefore it's 32 sample in total.

\section{Data Analysis and Hypotheses Test}

Since there is moderating variable involved in this study, we use moderated regression analysis and multiple regression analysis. Before we conduct moderated regression analysis and multiple regression analysis, first,we have to test for classic assumption. There are four test included, which are normality test, autocorrelation test, multicolinearity test, and heteroskedastisity test. Figure 1 shows research model used in this study. 


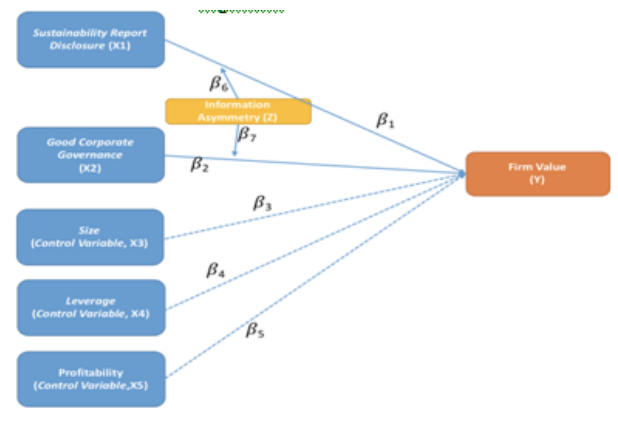

Figure 1

Research Model

Based on research model above, the equation used in this study are:

(1) $\mathrm{Y}=\alpha_{1}+\beta_{1} \mathrm{X}_{1}+\beta_{2} \mathrm{X}_{2}+\beta_{3} \mathrm{X}_{3}+\beta_{4} \mathrm{X}_{4}+$ $\beta_{5} \mathrm{X}_{5}+\varepsilon$

(2) $\mathrm{Y}=\alpha_{1}+\beta_{1} \mathrm{X}_{1}+\beta_{2} \mathrm{X}_{2}+\beta_{3} \mathrm{X}_{3}+\beta_{4} \mathrm{X}_{4}+$ $\beta_{5} \mathrm{X}_{5}+\beta_{6} \mathrm{ZX}_{1}+\varepsilon$

(3) $\mathrm{Y}=\alpha_{1}+\beta_{1} \mathrm{X}_{1}+\beta_{2} \mathrm{X}_{2}+\beta_{3} \mathrm{X}_{3}+\beta_{4} \mathrm{X}_{4}+$ $\beta_{5} \mathrm{X}_{5}+\beta_{7} \mathrm{ZX}_{2}+\varepsilon$

Keterangan:

$\mathrm{Y} \quad=$ Firm Value

$\mathrm{X}_{1}=$ Sustainability Report Disclosure

$\mathrm{X}_{2}=$ Good Corporate Governance (GCG)

$\mathrm{X}_{3} \quad=$ Size

$\mathrm{X}_{4} \quad=$ Leverage

$\mathrm{X}_{5} \quad=$ Profitability

$\mathrm{Z}=$ Information asymmetry

$\alpha \quad=$ Constanta

$\beta_{1} \beta_{2} \beta_{3} \beta_{4} \beta_{5} \quad=$ regression coefficient

$\varepsilon \quad=$ error standard

$\mathrm{Z}$ variables is moderating variable, thus $\beta_{6}$ and $\beta_{7}$ coefficient have to be significant at 0.05 . Equation (1) shows equation for the multiple regression analysis, meanwhile Equation (2) and (3) shows equation for moderated regression analysis.

Hypotheses test for this study use partial test (t test) and simultaneously test (f test). Partial test is use to show how much influence that independent variable has over dependent variable. While simultaneously test is to find out does all the independent variable have influence over dependent variable. And also this study conduct determination coefficient test to measure 250 how well the regression line fit with it's data.

\section{Results}

\section{Descriptive Results}

There is something very interesting we found in this study. As seen at Table 3, SRDI Score in 2012-2013 tend to be higher than 2014-2015. We further analyze that these phenomena happened because of new GRI Guidelines. In 2014-2015 most of the firm use GRI G4 Guidelines, while in 20122013 most of them use GRI 3.1. GRI G4 have option to decide which item to be disclosed. There are two option, "core" and "comprehensive". If a firm, choose "core" option they only have to disclose minimum 34 item on general aspects, and one tem on environmental, social, and economic aspect. Meanwhile, if a firm choose "comprehensive" option, they have to disclose all item in GRI G4 Guidelines. Surely, if firm are given two option that benefit their behalf, they will choose that option, in this case they choose the minimum disclosed item, "core" option.

Almost all of the sample have most trusted company rating (CGPI Score more than or same as 85 point), which is as much as 24 sample or almost $75 \%$ of all the sample. While the rest are trusted company rating (CGPI Score more than or same as 70 point)as much as 8 sample or $25 \%$ of all the sample. This is show that most firm are very committed to practice their GCG. On table 2 column Var X3 (Size), shows that banking industry is the biggest four in term of total asset. While others show smaller size of asset. Same thing happens with Var $\mathrm{X} 4$ (Leverage). As seen in table 2 column Var X5 (profitability, measured with ROA) have an interesting value. ANTAM have a dramatic decrease over the years. IN 2012 their ROA is $15,19 \%$, then drastically decrease to $1,87 \%$, have a small increase in 2014 to $3,52 \%$ but then again took the fall in 2015 to $-4,75 \%$. While in banking industry, their ROA never go over $5 \%$. 
Even tough never go above 5\%, but it shows that banking industry have stability that others don't have.

Table 3

\section{Variables Data}
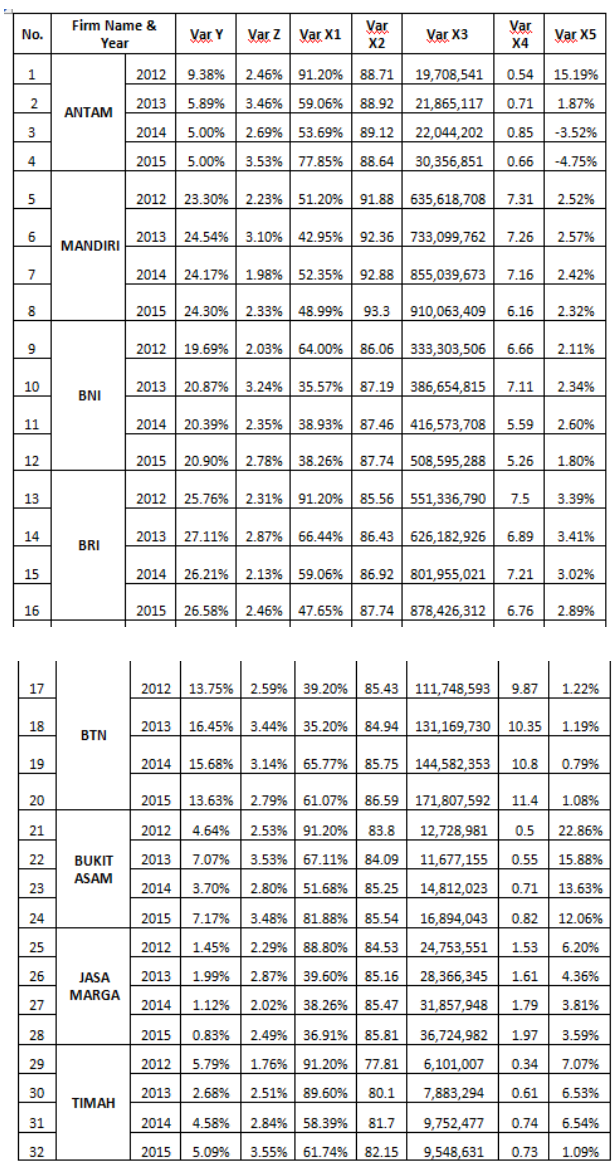

In Table 2 shows that the highest information asymmetry value is $3,55 \%$ and the lowest at $1,76 \%$, surprisingly both held by TIMAH. Also there are vary fluctuation. In 4 years there is up and down with no patterns whatsoever. While the average is stabilizing at $2-3 \%$ point. Highest firm value is held by MANDIRI in 2013 at $27,11 \%$. And the yearly average holding steadily around $12,60 \%-13,32 \%$ for every firm. This average surely did not clearly explain all of the sample since there is huge gap between every sample. Also, as seen in Table 2 column Var Y, high firm value is dominated by banking industry.

\section{Statistical Results}

\section{Classical Assumption Test}

At first we conduct normality test. As seen Figure 2 below, it shows that the dots still following the diagonal line, so it concluded that the data spread is normally distributed. Second test, autocorrelation test result is shown below in Table 4. Since the Durbin Watson value is 0,909 , which is between -2 and 2, then as per criteria it is said that the data used doesn't have autocorrelation problem.

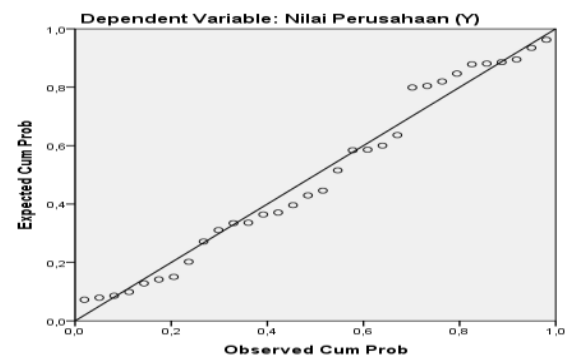

Figure 2

\section{P-Plot Graphic}

Table 4

Autocorrelation Test Result

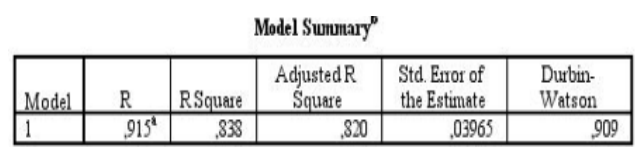

Third test, multicollinearity test result shows that this study has a tolerance value for each variable $>0,1$ and Variance Inflation Factor (VIF) less than 10. It means that there are no sign of strong correlation between independent variable thus multicollinearity assumption is fulfill. 


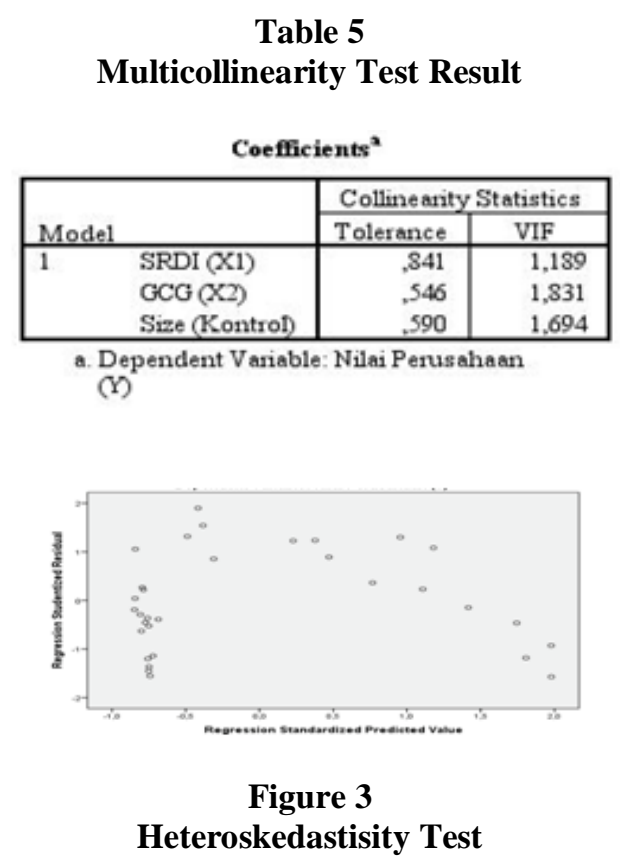

The last test is heteroskedastisity test. It is used to find out if the regression model has a similarity varians from one observation residual with other observation. From graphic below, it can be seen that the dots form a random pattern and spread above and below zero on Y line. Thus, it doesn't found any heteroskedastisity breach.

\section{Regression Analysis}

Multiple regression analysis result shown in Table 6 as follows.

Table 6

\section{Multiple Regression Analysis Result}

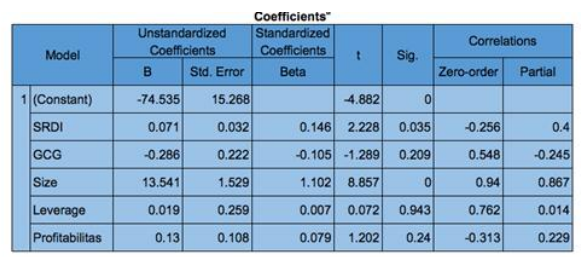

Thus, the equation is $\mathrm{Y}=-74,5.35+$ $0,071 \mathrm{X} 1-0,286 \mathrm{X} 2+13,541 \mathrm{X} 3+0,019 \mathrm{X} 4+$ $0,13 \times 5$. This means that:

a. The constant of $-74,535$ denotes the prediction of firm value when the independent variable is zero (0).

b. Variable X1 that is SRDI has regression coefficient value equal to 0,071 indicate that when disclosure of SRDI increased $1 \%$, predicted will increase firm value as much as 0,071 percent.

c. X2 variable that is GCG has regression coefficient value equal to -0.266 indicates that when GCG is increased 1 time, it is predicted will decrease firm value equal to 0,286 percent.

d. X3 variable that size has regression coefficient value of 13,541 , indicating that when size is increased 1 million, predicted will increase firm value equal to 13,541 percent.

e. $\mathrm{X} 4$ variable that is leverage has regression coefficient value of 0,019 , indicating that when leverage is increased 1 time, predicted will increase firm value equal to 0,019 percent.

f. Variable X5 that is profitability have value of regression coefficient equal to 0,13 , indicate that when profitability increase $1 \%$ predicted will increase firm value equal to 0,13 percent.

As for partial coefficient determinant, the result shown in Table 7 below. 
Table 7

Partial Coefficient Determinant

\begin{tabular}{|l|l|r|r|}
\hline \multicolumn{3}{|c|}{ Coefficients $^{*}$} \\
\hline \multirow{2}{*}{ Model } & $\begin{array}{c}\text { Standardized } \\
\text { Coefficients }\end{array}$ & Correlations \\
\cline { 3 - 5 } & \multicolumn{1}{|c|}{ Beta } & Zero-order \\
\hline \multirow{3}{*}{1} & SRDI & 0.146 & -0.256 \\
\cline { 2 - 4 } & GCG & -0.105 & 0.548 \\
\cline { 2 - 4 } & Size & 1.102 & 0.84 \\
\cline { 2 - 4 } & Leverage & 0.007 & 0.762 \\
\cline { 2 - 4 } & Profitabilitas & 0.079 & -0.313 \\
\hline
\end{tabular}

b. Dependent Variable: Nilai_Perusahaan $(Y)$

Based on the table above, means that;

a. The effect of $\mathrm{X} 1$ on $\mathrm{Y}=0.146 \mathrm{x}$ $0.256=-0.0374$ or $-3.74 \%$

b. The effect of $\mathrm{X} 2$ on $\mathrm{Y}=-0.105 \mathrm{x}$ $0.548=-0.0575$ or $-5.75 \%$

c. The effect of $\mathrm{X} 3$ on $\mathrm{Y}=1.102 \mathrm{x}$ $0.840=0.9257$ or $92.57 \%$

d. The effect of $\mathrm{X} 4$ on $\mathrm{Y}=0.007 \mathrm{x}$ $0.762=0.0053$ or $0.53 \%$

e. The effect of $\mathrm{X} 5$ on $\mathrm{Y}=0.079 \mathrm{x}$ $0.313=-0.0247$ or $-2.47 \%$

According to Table 8, highlighted blue is the variable beside variable control that have significant influence on firm value, which is sustainability report disclosure. The t-table value is 2,228 while the $\mathrm{t}$-count is 2,056 . This means partially disclosure of sustainability report has significant influence to firm value at CGPI participant 2012 - 2015 period. Same thing with variable control (X3), size, it's t-table is higher than t-count. While GCG t-table is lower than t-count $(-1,289<2,056)$, means partially GCG has no significant influence to firm value at CGPI participant 2012 - 2015 period, similar with the rest of variable control, leverage and profitability.
Table 8 Partially Hypotheses Test

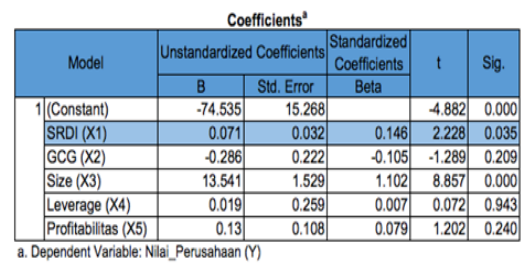

Meanwhile the simultaneously hypotheses test show that sustainability report disclosure and GCG have significant influence on firm value at CGPI participant 2012 - 2015 period. It based on the test result below on Table 9. The F-count is higher than F-table, 60,850>4,74.

\section{Table 9}

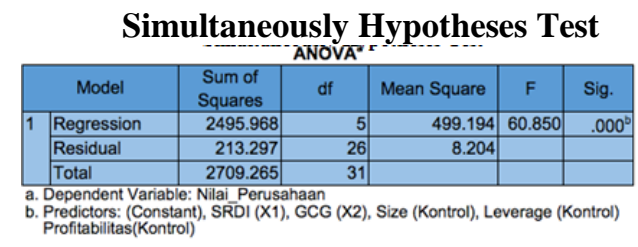

Below we explained the result of moderated regression analysis. Based on the below output table (Table 10), it can be seen that the coefficient of determination obtained is 0.919 or $91.9 \%$. This shows that the sustainability report disclosure and sustainability report disclosure interaction with information asymmetry contributed to the company value of $91.9 \%$, while the rest of the other $8.1 \%$ is the contribution of other variables that are not examined.

Table 10

First Interaction Coefficient Determinant

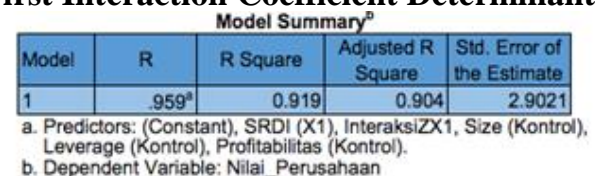

Based on the below output table (Table 11), it can be seen that the $t$-count value obtained by the interaction between the disclosure of sustainability report with 
information asymmetry is 2,972 with significance value of $0,034<0,05$. Thus, it can be concluded that partially, the disclosure of sustainability report and the interaction between sustainability report disclosure and information asymmetry have significant effect on the value of CGPI participant companies in 2012 - 2015.

Table 11

Partial Hypotheses Test

\begin{tabular}{|c|c|c|c|c|c|c|}
\hline \multicolumn{7}{|c|}{ Coefficients ${ }^{a}$} \\
\hline & \multirow{2}{*}{ Model } & \multicolumn{2}{|c|}{$\begin{array}{l}\text { Unstandardized } \\
\text { Coefficients }\end{array}$} & \multirow{2}{*}{$\begin{array}{c}\text { Standardized } \\
\text { Coefficients } \\
\text { Beta }\end{array}$} & \multirow[t]{2}{*}{$t$} & \multirow{2}{*}{ Sig. } \\
\hline & & B & Std. Error & & & \\
\hline \multirow[t]{6}{*}{1} & (Constant) & -93.282 & 9.77 & & -9.547 & 0 \\
\hline & SRDI & 0.043 & 0.049 & 0.088 & 0.884 & 0.385 \\
\hline & InteraksiZX1 & 0.216 & 0.116 & 0.098 & 2.972 & 0.034 \\
\hline & Size & 12.6 & 1.234 & 1.025 & 10.213 & 0 \\
\hline & Leverage & 0.134 & 0.242 & 0.053 & 0.555 & 0.583 \\
\hline & Profitabilitas & 0.149 & 0.11 & 0.09 & 1.352 & 0.188 \\
\hline
\end{tabular}

After we calculate the influence for first interaction to prove third hypotheses, we conduct second interaction to prove fourth hypotheses. Based on the below Table 12, it can be seen that the coefficient of determination obtained is 0.914 or $91.4 \%$. This shows that GCG and GCG interaction with information asymmetry contributes $91.4 \%$ to corporate value, while the remaining $8.6 \%$ is contributed by other unresearched variables.

\section{Table 12}

\section{First Interaction Coefficient Determinant}

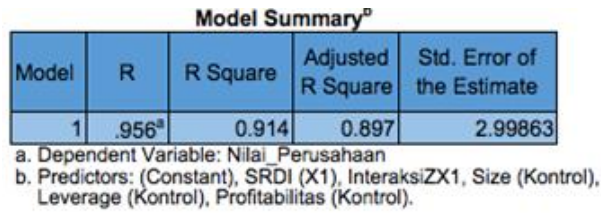

Based on the above output table, it can be seen that the t-calculated value obtained by interaction between GCG with information asymmetry is 1,500 with significance value equal to $0,146>0,05$ indicating that information asymmetry weaken the relationship between GCG and company value at CGPI participant company in 2012 -2015 .
Table 13

Partial Hypotheses Test

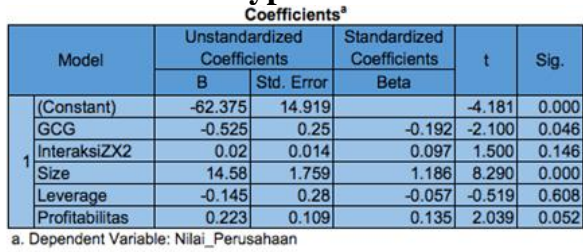

\section{Discussion}

\section{First Hypothesis}

The results of this study indicate that investors have a positive perception of business activities undertaken by the company, so that investors are more interested to invest in the company. The statement is supported by research conducted by Bachoo, et al (2013), and Fatchan and Trisnawati (2016). In addition, it also proves that the manager's initiative in increasing the firm value by issuing a sustainability report indicates a goingconcern.Bachoo, et al (2013), and Fatchan and Trisnawati (2016) mentioned that investors who invest in companies that publish good sustainability reports earn better confidence and lower risk than investing in companies that do otherwise. Other researchers who found similar things were Plumlee et al (2015). Plumlee, et al (2015) presented the same evidence from the results of the regression analysis.

However, the results of this test are contrary to the research that has been done by Dobre, et al (2015) and Dagilienè (2013). They prove that the disclosure of sustainability report has no effect on company value. And Dagilienè (2013) who conducted research in Lithuania on the influence of CSR reporting on firm value, proves that companies with high CSR reporting scores, do not have high corporate value as well.Based on the results of statistics that have been done and supported by the results of previous research, it can be concluded that with the initiative of companies to publish sustainability report 
provides a positive signal for investors to invest in the company. In addition, the disclosure of a sustainability report is higher (the level of disclosure), providing a better level of confidence and a lower risk than investing in companies that do otherwise.

\section{Second Hypothesis}

This shows that the concept of fairness, transparency, accountability, responsibility, which is expected to be reflected through the CGPI rating can increase the value of the company, is not achieved. The results of this test support the research that has been done by Haat, et al (2008), Nuswandari (2009), Siregar and Riandi (2011), Zabri, et al (2016), and Gherghina (2015). They prove that GCG has no effect on corporate value. Gherghina (2015) examines the effect of corporate governance ratings on firm value on firms listing in Bucharest Stock Exchange (BSE). The proxy used by Gherghina (2016) to measure company value consists of two, namely accountingbased firm value measures (using ROA and ROE) and market-based firm value measures (using EPS). As for the measurement of corporate governance ratings using Principal Component Analysis (PCA).

The rejection of this hypothesis shows that investors do not make GCG as a consideration in the investment decisions of a company that ultimately determines the value of the company. This can be due to the fact that investors are not getting enough GCG information from CGPI scores alone. Given that this CGPI score was published in SWA Magazine, the report itself was not published unless the company requested the data directly to the IICG as an appraiser. So not all investors get the same information.

The statement is in line with the results of research conducted by Haat et al (2008). Research conducted in Malaysia shows that one of the causes of investors do not use GCG information in making investment decisions such as investors are not informed about the practice of a comprehensive GCG in a company.

This study may add to the literature on the absence of GCG influence on corporate value, since the majority of previous studies show the opposite, one of which is Zhu (2014). Zhu (2014) concludes that GCG has an influence on corporate value. Zhu (2014) conducted a study with corporate governance data obtained from the Institutional Shareholder Services (ISS) database for the period 2003-2006. The ISS database tracks 55 different corporate governance attributes from 22 developed countries except the United States, and provides 61 corporate governance attributes from the United States (Zhu, 2017: 397). Then Zhu (2017: 397) mentions, "The wide spectrum of governance attributes allows the construction of an overall governance rating as well as several subratings for different aspects of a firm's corporate governance practice." So for further research it can be considered to use the rating attribute more comprehensive in measuring the GCG of a company.

\section{Third Hypothesis}

The results of this study prove that the problems arising from agency theory in the practice of accounting is the existence of gaps between managers and principals (information asymmetry) one of which can be overcome with the initiative of managers publish a voluntary disclosure, in this case a sustainability report.This is in line with research conducted by Martinez-Ferrero, et al (2016). The results show that voluntary disclosure such as CSR can suppress information asymmetry which can then increase capital market confidence and ultimately increase company value (Martinez-Ferrero, et al, 2016: 229).

The disclosure of sustainability reports is considered capable of communicating information that has not been obtained by investors from the company's financial statements or annual 
reports. This is supported by the findings of Martinez-Ferrero, et al, (2016: 230):

"Through CSR or sustainability reports, which are derived from the principal-agent relationship."From those statement, Martinez-Ferrero, et al, (2016) emphasized that through CSR report and sustainability report investors get environmental and social information previously not available in the financial statements. It can reduce the asymmetry of information arising from agency problems. Then, these initiatives are valued by investors to be an important consideration in making investment decisions.

For other investors, the information contained in the sustainability report provides them with the necessary evidence to have knowledge of managerial commitment to social issues. Thus, the company successfully meets the needs of various stakeholders, legitimizing the actions and policies of their business operations to the public.

\section{Fourth Hypothesis}

This study can enrich the literature that discusses the influence of GCG on corporate values with information asymmetry as moderating variables are still little found. Research in line with these findings is Jamalinesari and Soheili (2015) and Daines, et al (2010). Jamalinesari and Soheili (2015) conducted a study on 145 companies from 22 industries during 20082013, indicating that there is one GCG mechanism that has no effect on information asymmetry.Information asymmetry does not moderate the influence of GCG on corporate value in this study could be due to CGPI scores that are considered not able to predict future firm value. This is supported by the results of research conducted by Daines, et al (2010: 460) which states that:

"Prior evidence on individual ratings has generally been backward-looking, raising the distinct possibility that the ratings reflect past performances but are not to predict future outcomes. We find that these governance ratings have limited or no success in predicting firm performance or other outcomes of interest to shareholders. Moreover, even when there is a statistical association with future out- comes, the substantive economic effect is small. "

Based on Daines, et al (2010) and the results of this study, it can be concluded that investors can not rely on the CGPI score as a solution to the information asymmetry that can be used as the basis for investment decision making. So the information asymmetry does not moderate the influence of GCG on corporate value.

This is in contrast to the research that has been done by Chen and Liu (2013). They conducted research on the influence of corporate governance practices affecting firm value under the conditions of information asymmetry. It then proves that the impact of GCG has significant effect on firm value, with increasingly reduced / reduced information asymmetry. Chen and Liu (2013) use the OLS regression research method, with information asymmetry as measured by the depth of disclosed credit information, GCG as measured by company ownership, and manager's experience, while firm value is measured by the amount of market capitalization.

\section{Conclusions}

The conclusions in this study are as follows:

a. Disclosure of sustainability report significantly influence the firm value in CGPI participant in 2012-2015.

b. GCG does not significantly affect the firm value in CGPI participating in 2012-2015.

c. The disclosure of sustainability report significantly influences firm value by moderated by information asymmetry at CGPI participant in 2012-2015.

d. GCG does not significantly affect firm value by being moderated by 
information asymmetry at CGPI participants in 2012-2015.

Based on the research conclusions that have been described previously, the suggestions given by researchers are as follows:

a. This research uses samples with various types of industries, therefore it is suggested for further researcher to use samples with companies that are in one kind of industry. So that it can examine one of the effects of disclosure sustainability report that is specific to certain corporate characteristics, such as environmental disclosure elements in sustainability report in companies in the mining industry.

b. The GCG measurements in this study are CGPI so that the sample criteria must be met, one of them must be a CGPI ranking participant, while the CGPI rating / the assessment itself is a voluntary activity. This results in a limited number of samples. It is therefore advisable to use other GCG measurements while remaining comprehensive and independent, or may be supplemented by interviews as confirmation and additional information on a company's GCG practices.

c. Research on the influence of GCG on firm value has been widely done both in Indonesia and outside Indonesia, but research that also includes information asymmetry in it is still small. Therefore, it is suggested to other researchers to include information asymmetry as a moderating variable in order to deepen the results of this study indicating that information asymmetry can not moderate the relationship of GCG influence to firm value.

\section{Reference}

Agoes, Sukrisno., Ardana, Cenik. 2014. Etika Bisnis dan Profesi: Tantangan Membangun Manusia Seutuhnya
Edisi Revisi Salemba Empat 2014 Jakarta

Akerlof, George A. (1970) The Market for "Lemons": Quality Uncertainty and the Market Mechanism. The Quarterly Journal of Economics, Vol. 84, No. 3. (Aug., 1970), pp. 488-500.

Bachoo, Kaveen., Tan, Rebecca., Wilson, Mark. 2013. Firm Value and the Quality of Sustainability Reporting in Australia. Australian Accounting Review No. 64 Vol. 23 Issue 12013 pp 67-87.

Bahmani, Dariush. 2014. The Relation between Disclosure Quality and Information Asymmetry: Empirical Evidence from Iran. Journal of Financial Research. Vol. 5 No. 2 2014 pp 110-114.

Bateh, Justin., Horner, Donald H., Broadbent, Ardell., Fish, David. 2014. Towards A Theoretical Integration of Sustainability: A Literature Review and Suggested Way Forward. Journal of Sustainability Management - June 2014 Volume 2, Number 1 hal 35-42

Becchetti, Leonardo., Ciciretti, Rocco. 2008. Corporate Social Responsibility and Stock Market Performance. CSR Paper 34.2008 pp 1-30

Byus, Kent., Deis, Donald., Ouyang, Bo. 2010. Doing Well by Doing Good: Corporate Social Responsibility and Profitability. S.A.M. Advanced Management Journal; Winter 2010; 75,1 ; pp. 44

Chen, Chen-Wen., Liu, Victor W. 2013. Corporate Governance Under Asymmetric Information: Theory and Evidence. Economic Modelling 33 (2013) pp 280-291

Claessens., Yurtoglu, Burcin. 2013. Corporate Governance in Emerging Markets: A Survey. Emerging Markets Review 152013 pp. 1-33. 
Dagiliene, Lina. (2013) The Influence of Corporate Social Reporting to Company's Value in A Developing Economy. Procedia Economics and Finance 5 (2013) $212-221$

Daines, Robert M., Gow, Ian D., Larcker, David F. (2010). Rating the Ratings: How Good Are Commercial Governance Ratings?Journal of Financial Economics 98 (2010) 439461.

Diebecker, Jan., Sommer, Friedrich. (2017). The Impact of Corporate Sustainability Performance on Information Asymmetry: The Role of Institutional Differences. Review of Managerial Science, 2017, vol. 11, issue 2 , pages $471-517$

Dobre, Elena., Stanila, Georgiana Oana., Brad, Laura (2015). The Influence of Environmental and Social Performance on Financial Performance: Evidence from Romania's Listed Entities. Sustainability Journal 2015, 7, 25132553

Donaldson, Thomas., Preston, Lee E. (1995). The Stakeholder Theory of the Corporation: Concepts, Evidence, And Implications. The Academy of Management Review, Vol. 20, No. 1 (Jan., 1995), pp. 6591

Eisenhardt, K.M., 1989. Agency theory: An assessment and review. Academy of management review, 14(1), pp.5774.

EY and Boston College (2016). Value of Sustainability Reporting: A Study by $E Y$ and Boston College Center for Corporate Citizenship. EY \& The Carroll School of Management Center for Corporate Citizenship at Boston College 2016.

Fatchan, Ilham N., Trisnawati, Rina. (2016). Pengaruh Good Corporate Governance Pada Hubungan Antara Sustainability Report Dan Nilai
Perusahaan. Riset Akuntansi dan Keuangan Indonesia 1 (1) 2016 hal 25-34.

Fernando, A.C. (2006). Corporate Governance Principles, Policies and Practices. Dorling Kindersley Pvt. Ltd, licensees of Pearson Education in South Asia 2006

Freeman, R. Edward., and Reed David L. (1983). Stockholders and Stakeholders: A New Perspective on Corporate Governance. Management Review, Vol. 25 No. 3, Spring 1983.

GRI. (2013) GRI G4 Sustainability Reporting Guidelines: Reporting Principles and Standard Disclosures. Global Sustainability Standards Board.

Gherghina, Ştefan Cristian. (2015). Corporate Governance Ratings and Firm Value: Empirical Evidence from The Bucharest Stock Exchange. International Journal of Economics and Financial Issues Vol. 5, No. 1, 2015, pp.97-110

Haat, M Hassan Che., Rahman, Rashidah Abdul., Mahenthiran, Sakhti (2008). Corporate Governance, Transparency and Performance of Malaysian Companies. Managerial Auditing Journal Vol. 23 No. 8, pp. 744-778.

Hitchner, James R. (2017) Financial Valuation: Application and Model. John Wiley \& Sons, Inc. New Jersey, USA.

Jamalinesari, Shamsaldin., Soheili, Hossein (2015) "The Relationship between Information Asymmetry and Mechanisms of Corporate Governance of Companies in Tehran Stock Exchange" Procedia - Social and Behavioral Sciences 205 (2015) pp $505-509$.

Jensen, Michael C., Meckling, William H. (1976) "Theory of The Firm: Managerial Behavior, Agency Costs and Ownership Structure" Journal 
of Financial Economics. Volume 3, Issue 4, October 1976, Pages 305360

Jones, Charles P. (2013) Investments Analysis and Management $12^{\text {th }}$ Edition. John Wiley \& Sons, Inc.USA.

Kipp, Peter and Tadesse, Amanuel F., Zhang, Yibo James. (2017) The Impact of Social Media Message Features on Investors' Perception of Firm Value: The Mediating Effect of Social Media Interactions (January 23, 2017). Available at SSRN: https://ssrn.com/abstract $=2904677$

Martinez-Ferrero J, Ruiz-Cano D, GarciaSanchez IM (2016). The Causal Link Between CSR Disclosure and Information Asymmetry: The Moderating Role of the Stakeholder Protection Context. Corporate Social Responsibility and Environmental Managemebt 23:319-332.

Mishkin, Frederic S., Eakins, Stanley G. (2015). Financial Markets and Institutions $8^{\text {th }}$ Edition. United States: Pearson Education.

Nuswandari, Cahyani. (2009). Pengaruh Corporate Governance Perception Index terhadap Kinerja Perusahaan pada Perusahaan yang Terdaftar di Bursa Efek Jakarta. Jurnal Bisnis dan Akuntansi, 16(2), hal. 70- 84.

Plumlee, Marlene., Brown, Darrel., Hayes, Rachel M., Marshall, R. Scott. (2015). Voluntary Environmental Disclosure Quality and Firm Value: Further Evidence. Journal of Accounting and Public Policy Vol. 34, Issue 4, July-August 2015, pp 336-361.

Putra, Adrie., Simanungkalit, Royhisar Martahan. (2014). The Impact of Implementation Good Corporate Governance to Firm Value (Evidence from Indonesia Public Banking Sector). Review of Integrative Business \& Economics Research Vol 4 (1) 2014 pp 95-102.
Randy, Vincentius., Juniarti (2013). Pengaruh Penerapan Good Corporate Governance Terhadap Nilai Perusahaan Yang Terdaftar di BEI 2007-2011. Business Accounting Review, Vol. 1, No. 2, 2013

Riandi, Dani., Siregar, Hasan Sakti. (2011). Pengaruh Penerapan Good Corporate Governance terhadap ROA, NPM dan EPS pada Perusahaan yang Terdaftar di CGPI. Jurnal Ekonomi Volume 14 Nomor 3.

SemeNova, Natalia., HaSSel, LarS G., NilSSoN, HeNrik (2009). The Value Relevance of Environmental and Social Performance: Evidence from Swedish SIX 300 Companies. LTA 3/10 p. 265-292.

Siew, Renard Y.J., Balatbbat, Maria C.A., Carmichael, David G. (2013) The Relationship Between Sustainability Practices and Financial Performance of Construction Companies. Smart and Sustainable Built Environment Vol. 2 No. 1, 2013 pp. 6-27

Siregar, Hasan Sakti., Riandi, Dani. 2011. Pengaruh Penerapan Good Corporate Governance terhadap ROA, NPM dan EPS pada Perusahaan yang Terdaftar di CGPI. Jurnal Ekonomi Volume 14 Nomor 3.

The Bruntland Report. 1987. Report of the United Nation World Commission on Environment and Development (WCED): Our Common Future.

The State of CSR Reporting and Communications 2016: The Ethical Corporation CSR Reporting and Communications Report 2016. Ethical Corporation London, UK 2016.

Zabri, Shafie Mohamed et al., (2016) Corporate Governance Practices and Firm Performance: Evidence from Top 100 Public Listed 
Jurnal Akuntansi Maranathan Volume 10 Nomor 2, November 2018 : 241-260

Companies in Malaysia. Procedia Economics and Finance 35 (2016) page $287-296$.

Zhu, Feifei (2014). Corporate Governance and the Cost of Capital: An International Study. International Review of Finance, 14:3, 2014: pp. 393-429

AICPA (2016) "Sustainability Accounting and Reporting" diakses dari https://www.aicpa.org/InterestAreas/ BusinessIndustryAndGovernment/R esources/Sustainability/Pages/Sustai nabilityFAQs.aspx pada tanggal 10 November 2016 pukul 21.07 